\title{
SMART
}

SMART

(Journal of English Language Teaching and Applied Linguistics)

Volume 7, No. 1, January 2021 Page. 1 - 6

p-ISSN: 2356-2048 e-ISSN: 2356-203x

\section{SELF TALK STRATEGY IN IMPROVING THE ELEVENTH GRADE STUDENTS' SPEAKING ABILITY}

\author{
Hermansyah \\ English Education Department, Universitas PGRI Palembang \\ Email Correspondance: hermansyah@univpgri-palembang.ac.id
}

\begin{abstract}
Self-talk strategy is making positive statements like "I can do this" to help oneself get through challenging tasks. This study used a quasi-experimental method. The population was the eleventh-grade students of Muhammadiyah Senior High School of Palembang, with the total sample of this research was 60 students. The data were collected through an oral test and analyzed by using a t-test to know significant difference between the students' achievement in the experimental group and control group. Based on this study, it was found that Self Talk strategy was effective in teaching students speaking skills.
\end{abstract}

Key words: strategy, speaking, self talk.

\section{INTRODUCTION}

Since indonesian independence in 1945, English has been taught in Indonesia as a compulsory subject for junior high school, senior high school, and the first year of university, (1997). In communication, English is one of international language. It needs the ability for speaking to make a communication. Brown (1994) states one of the major obstacles learners has to overcome in learning to speak is the anxiety generated over the risks of blurting things out that are wrong, stupid, or incomprehensible. Because of the language ego that informs people that "you are what you speak," learners are reluctant to be judged by hearers. Our job as the teachers is to provide the kind of warm, embracing climate that encourages students to speak however halting or broken those attempts may be. One of the more complicated problems of second language learning and teaching has been defining and applying the construct of motivation in the classroom.

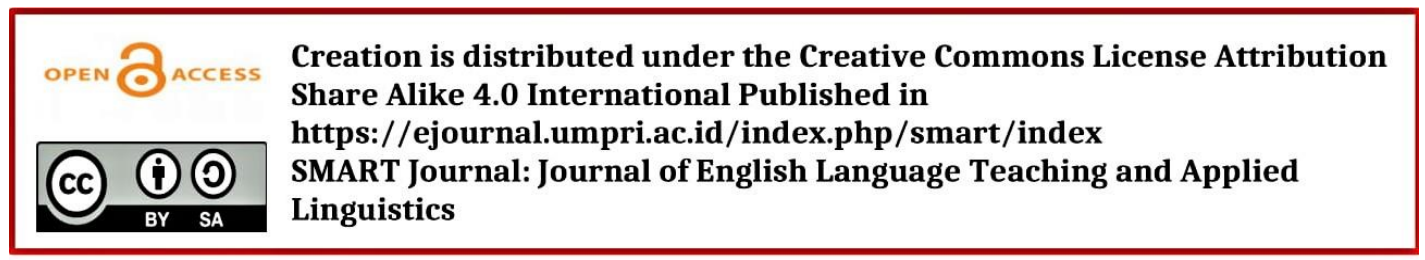




\section{Hermansyah....}

Students of Muhammadiyah Senior High School 6 of Palembang in the classroom got the problems for speaking English. They were unable to express their ideas by using speaking English. But the most important one, the problems come out from themselves. It is about self confidence and motivation. They have intention to speak in English, but they are afraid to get a mistake and pressure of many aspects.

In the classroom, when students have opportunities to make their own choices about what to pursue and what not to pursue, as in a cooperative learning context, they are fulfilling this need for autonomy. According to $\mathrm{Wu}$ (2012) the internal factors, such as correct attitude and intense motivation are very important for students to learn and speak English well. The intensity of motivation usually varies with the changes of time and surroundings. On the other hand, Hermansyah (2018) delivers that social surroundings could also affect one's attitude towards life and learning. Attitude, anxiety, motivation, personality, self-esteem, and self confidence are important and affective factors. The advanced learners are usually highly motivated in these factors. This study focuses on students for improving speaking English. The writer will encourage students who should be able to express what they are thinking and feeling. Actually, they need motivation to encourage their speaking English. In speaking, many students cannot use it. They just focus on grammar without practising to speak. This is one of problems for students in English. They understand about English, but they cannot speak in English. They get difficulty and make speaking to be difficulty.

Reassuring yourself while doing a difficult task may help you do more than you thought you could because even if you cannot do the task perfectly you can probably do some of it. They can think about learning strategies that have been successful for them in the past to help them solve problems at hand. When the students speak, they can use self talk strategy as their step to try speaking. The writer gave question about themselves, so they can easily share themselves in speaking. High motivation is the way to improve speaking skill, because it is the first step to increase self confidence in speaking. Accidentally, they speak in English to express their thought and feeling. 


\section{RESEARCH METHOD}

In this research, the experimental method will be used. The term of experimental method is the experiment done by manupulating the objects of the study with the control. The goal of this method is to observe whether or not the correlation and significance by giving the certain treatment to the experimental group and provide a control for comparison. (Nazir, Momammad, 1988) In doing investigation, the following steps took; Identifying some relevant books, Identifying and defining the research problems, Giving treatment, and Writing the report as a thesis.

The population of this study was all the eleventh grade students at Muhammadiyah Senior High School 6 of Palembang. This population was chosen because were found some of problems about students' speaking skill and then they do not have strategies to solve their problems, so that this research would be conducted in this school with those reasons.

The data analyzed was taken from the tests. The writer devides the students' scores into two groups. Group A: The scores of the pre-test and post-test of the students who learned speaking through self talk strategy. Groups B: The scores of the pre-test and post-test of the students who learned speaking by using traditional method

In this study, the writer presented the data distrubution of each test of both two groups in the form of the raw score, then the writer analyzed the data statistically by Inter-rater reliability and SPSS Program.

\section{FINDINGS AND DISCUSSION}

The test consisted of four aspects by using self- talk strategy, there were four aspects measured in the test: pronunciation, expression, fluency and vocabulary. The result of test had two raters and from the result of test, the score was calculated by using SPSS program.

The findings of the study showed that the students' problems in speaking English not only beacause of the components of speaking such as; pronunciation, expression, vocabulary, and fluency but it could be comes from themselves those are 


\section{Hermansyah....}

encouragement, confidence and bravery. Jaya, et al (2018) mentions that in teaching speaking, the students should be raised their self confidence. Thus, when the students do not have encouragement, confidence and bravery to express their ideas in English. Jaya, et al (2018) adds that before English teachers start teaching, they should eliminate the problems on the students first, such as the students' motivation to learn. It means the problem comes out from themselves and it because of the students are not motivated to express their ideas in English. So that the teachers of English now on must have solution for the students. So, the one of solutions for the students is self talk strategy, because it the way that can motivate, encourage, and improve the students' confidence and bravery because with self talk strategy we can give positive statements for the students and it's really influence the students themselves.

Based on the result of research we can see the differences between scores in both post test in two samples, those are experimental and control group from two raters. We can see that there were significant improvement in students' speaking skill from post test in experimental group because there were many students got score in good level, it showed that teaching speaking English to the eleventh grade students of Muhammadiyah Senior High School 6 of Palembang is effective and it can be one of alternative way in teaching speaking skill.

On the other hand we can see there were no significant improvement in students' speaking skill from post test in control group because there were no students got score in good level, we can see from each pie charts from each group there were many differences of scores.

\section{CONCLUSION}

After analyzing the results of the study, the writer find out that teaching through self talk strategy as one of the effective ways to teaching speaking skill to the students.It can be seen that students' scores in post-test was higher than scores in pre-test. In other words, the students who were taught by using self talk strategy tend to be braver, more confident and of course be better It was also related to the result of the study conducted 
by Jaya et al (2018) that teaching speaking could be effective when the teachers of English apply the appropriate strategy such as self talk strategy . Therefore, self talk strategy could be used as the alternative way in teaching speaking.

\section{REFERENCES}

Anggraini, Sri. (2012). Improving Speaking Skill Through Self Talk Strategy of the Eleventh Grade Students of MAN 1 Palembang. Unpublished Undergraduated Thesis. Palembang: The University of Muhammadiyah.

Arikunto, Suharsimi. (2010). Prosedur Penelitian: Suatu Pendekatan Praktik, Edisi Revisi VI. Jakarta: Rhineka Cipta.

Barnhardt, Sarah. (1997). An Effective Strategy For Increasing Self Efficacy: SelfTalk. The language resource, vol $(1,5): 44$.

Blackmer,D. (2002). Mental Toughness Training for Peak Sport Performance. Accessed from www.TheExtraGear.com on Friday, 17th, May, 2013.

Brown, Doglas, H. (1994). Teaching by Principles; An Interactive Approach to Language Pedagogy. New Jersey: San Francisco State University, Prentice Hall Regent Englewood Clifs.

Bull, Victoria. (2009). Oxford Learner's Pocket Dictionary. New York: Oxford University Press.

Firdaus, Ferry. (1996). The Self Concepts of The First Year Students OfSMA 1 Palembang Their Reading Comprehension Achievement. Unpublished Undergraduated Thesis. Palembang: University of Sriwijaya.

Fraenkel, Jack R and Norman E Wallen. (1990). Hot to Design and Evaluate Research in Education, New York: Mc Graw-Hill Block. Co

Jaya, A. Hermansyah, Mortini, A. (2018). The Effect of Crawford Series Teaching (CST) on the Students' Writing Achievement. ESTEEM Journal of English Study Program. 1(1).

Jaya, A. (2017). The Influence of Teachers' Questioning Strategies on the Eleventh Grade Students' Speaking Achievement at SMKN 1 Palembang.Jambi-English Language Teaching. 2 (1). 
Hall, Marie Mount, (2013). Teaching Resource Guide. Washington, DC: University of Maryland College Park, MD 20742

Hatch, Evelyn and Hossein Farhady. (1982). Research Design and Statistics of Applied Linguistics. Cambridge: Newbury House Publisher.

Hermansyah. 2018. The Use of Grammar Consciousness Raising in Teaching Grammar. Holistic Journal , Vol 16,No.4

Hoge, AJ. (2012). Powerful English Speaking. Accessed from www.EffortlessEnglishClub.comon Tuesday, 25th, February, 2014.

Krashen, Stephen. (1983). The natural Approach. Oxford: Pergamon Press.

Pascal, Chris. (2011). Definitons of Teaching and School Readiness. Birmingham: Early Education Group.

Ratnasari, Dwi. (2012). English Learning Strategies. Palembang: Tunas Gemilang Press.

Richard, Jack C and Renandya, W., A. (1997). Methodology in Language Teaching. Cambridge: Cambridge University Press. 